Arch. Tierz., Dummerstorf 49 (2006) 1, 41-54

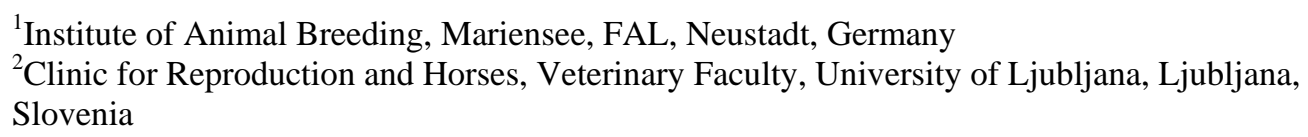

PRIMOZ KLINC ${ }^{2}$ and DETHLEF RATH ${ }^{1}$

\title{
Application of flowcytometrically sexed spermatozoa in different farm animal species: a review
}

\begin{abstract}
The most efficient way to shift the sex ratio of offspring is to select spermatozoa according to the sex chromosomes. The difference of their DNA-content can be used by flowcytometry to produce populations of either sex at high accuracy. As the method is based on single cell identification, the output of cells is limited, although major improvements were made by high-speed flowcytometry and improved cell orientation in front of the UV-Laser. The state of art is described in this review for the main farm animal species. For bovine AI sexsorted-frozen spermatozoa are already available on commercial basis, whereas in other species, especially in pigs, the high demand of spermatozoa can hardly be satisfied. However, in combination with other biotechniques like IVF, ICSI, GIFT and special insemination protocols litters of acceptable size were produced under laboratory condition. As in horses and sheep current research is focused in pigs on long time storage of the sex sorted spermatozoa in liquid nitrogen.
\end{abstract}

Key Words: sperm sexing, cattle, pigs, sheep, horse

\section{Zusammenfassung}

Titel der Arbeit: Stand und Perspektiven des Einsatzes von durchflusszytometrisch „gesexten“ Spermien bei verschiedenen Nutztierarten - Eine Übersicht

Die effizienteste Art, das Geschlechterverhältnis von Nachkommen zu beeinflussen, besteht darin, Spermatozoen entsprechend den Geschlechtschromosomen einzusetzen. Der Unterschied in der DNA-Menge zwischen X-bzw. Y-chromosomentragenden Spermatozoen kann genutzt werden, um Tierpopulationen jedes Geschlechts mit hoher Sicherheit zu erzeugen. Da die Methode auf der Identifikation einzelner Zellen basiert, ist die Sortierkapazität trotz erheblicher Fortschritte begrenzt. Der Stand der Technik wird für verschiedene Nutztierarten beschrieben. Für die Besamung von Rindern stehen separierte Samenzellen kommerziell zur Verfügung. Demgegenüber können die Anforderungen auf dem Gebiet der Besamung von Sauen mit separierten Spermatozoen derzeit kaum erfüllt werden. Jedoch wurden Würfe akzeptabler Größe in Verbindung mit anderen Biotechniken und speziellen Besamungsprotokollen unter Laborbedingung produziert. Die Forschung wird darauf konzentriert, sortierte Samenzellen der Spezies Pferd, Schaf und Schwein erfolgreich im flüssigen Stickstoff lagern zu können.

Schlüsselwörter: Spermientrennung, Rind, Schwein, Schaf, Pferd

\section{Introduction}

Modern livestock management requires efficient methods to optimize herd size avoiding non or suboptimal producing animals (SEIDEL JR., 2003). Especially, when products are sex related, the opposite sex diminishes farm efficiency. Besides, environmental reasons need to be taken in account showing that high productivity of animals is more beneficial compared to low or average performance, because basic metabolism is almost independent from the level of performance. Therefore, many attempts have been reported over the last decades to modify the sex ratio of offspring. In the bovine for example, females are required for milk production; whereas males are more preferable for meet production. With sorted spermatozoa, test inseminations 
can be reduced, and calving problems be avoided. In pig production, female end products are preferably requested and hybrid lines would benefit from sex preselection, whereas in companion animals owners demands may differ.

\section{Sex predetermination - historical development}

Since ancient times, sex determination has been of interest for man. First attempts to control sex have been described by philosophers in pre-ancient Greece. DEMOCRITUS OF ABADERA (460-370 BC) believed that males originate from the right testicle and females from the left. Further, it was said that males developed more often in the right and females in the left uterine horn. According to this presumption, recommendations for human coitus and in some instances even castration of "unwanted" testis were performed in order to obtain a child of the desired sex. First description of "Sperma" came from HIPPOCRATES (460-377 BC). He believed that "Sperma" plays a key role in the development of a child. If "Sperma", interestingly produced from both sexes, was strong from both parents, then a male would be born. In opposite "weak Sperma" was correlated with the development of a girl. Different selective strategies for gender pre-selection were developed on these assumptions and claims of other philosophers. Although ANTON VAN LEEUWEHOEK (1677) described spermatozoa for the first time using an improved microscope, real scientific approaches of gender pre-selection were first undertaken in the $20^{\text {th }}$ century with the development of more sophisticated instruments (HUNTER, 1995).

\section{Natural mechanism of sex determination}

Nature has developed several systems to maintain a balanced distribution of genetic information including sex related mechanisms within the population. Major impacts on the development of such systems are related to environmental dependence of a species. For example, in many reptiles, temperature depending enzymes regulate the sex of offspring (DORIZZI et al., 1996; GABRIEL et al., 2001; PIEAU et al., 2001). However, in some reptile species, sex is determined chromosomally depending on the combination of sex chromosomes ( $\mathrm{ZW}$ vs. $\mathrm{ZZ}$ ) as found in lizards and turtles (CORIAT et al., 1994).

In mammals and avian species, primary regulation of sex determination depends on chromosomal information only. Whereas in the latter female gametes are heterogametic, mammalian spermatozoa carry either a Y- or X-chromosome (DAVIS, 1981; JACOBS and STRONG, 1959; MCLAREN and MONK, 1981). The Ychromosome carries the genetic information for a testis-determining factor (TDF) that initiates the formation of testicular material in the primitive genital ridge. Secondarily, the morphological and functional development of the male genital apparatus is mainly hormonal dependent and suppresses in parallel development of the female genital tract. A precise localization of the TDF region and the genes that are included in sex differentiation were investigated comparatively between XY and XX males. DNA of these individuals includes different amount of Y-chromosome and their analysis allowed to map the short arm of Y-chromosome (MÜLLER et al., 1986). Further analysis of this region reveled that more genes are involved in sex differentiation. Cloning and screening of this region first discovered the zinc-finger gene on the Ychromosome (ZFY) believed to be the testis determination factor (TDF; PAGE et al., 1987). However, evidence was provided that ZFY cannot be the TDF, because some of XX males were ZFY negative (PALMER et al., 1989). Another candidate for TDF is 
the "sex region on the Y-chromosome" (SRY), which was discovered shortly after ZFY. Expression studies, mutational analysis of SRY in XY females, production of transgenic mice, and biochemical analysis provided further evidence that SRY is TDF (HARLEY et al., 1992; JAGER et al., 1990; KOOPMAN et al., 1990; KOOPMAN et al., 1991).

\section{Techniques to identify sex-related characteristics of spermatozoa}

The most effective way to influence sex ratios in offspring is to determine the sex before fertilization and therefore separate populations of $\mathrm{X}$ - and Y-chromosome bearing spermatozoa. Several techniques based on principals such as velocity (BEAL et al., 1984; BEERNINK and ERICSSON, 1982; DMOWSKI et al., 1979; ERICSSON et al., 1973; ZAVOS, 1985), density (BHATTACHARYA, 1958; BHATTACHARYA, 1962; BHATTACHARYA et al., 1966; FLAHERTY et al., 1997; KANEKO et al., 1983; KOBAYASHI et al., 2004; LOPEZ et al., 1993; PYRZAK, 1994; QUINLIVAN et al., 1982; ROHDE et al., 1975; ROSS et al., 1975; SCHILLING and THORMAEHLEN, 1977; SHASTRY et al., 1977; VIDAL et al., 1993; WANG et al., 1994b; WANG et al., 1994a), electric surface charge (BLOTTNER et al., 1994; ENGELMANN et al., 1988; MANGER et al., 1997; SEVINC, 1968; SHIRAI et al., 1974; SHISHITO et al., 1974; UWLAND and WILLEMS, 1975), and immunologically relevant structures (ALI et al., 1990; BENNETT and BOYSE, 1973; BLECHER et al., 1999; ERICKSON et al., 1981; HANCOCK, 1978; HENDRIKSEN et al., 1993; PINKEL et al., 1985; SILLS et al., 1998) have been developed and tested. None of these methods were able to produce statistically significant separation of fertile sperm populations, or were not repeatable.

The only method known so far uses the relative difference in DNA content of X- and Y- chromosome bearing spermatozoa. Research on DNA indicated by mid of the last century that its amount differs between the sex chromosomes. It led to the idea to identify spermatozoa on this basis. MORUZZI (1979) showed that the X-chromosome carries more DNA than the Y-chromosome, and that sperm autosomes have identical DNA content.

\section{Development of flowcytometrical sperm sorting}

At the same time, flowcytometry was developed (SPRENGER et al., 1971) and GLEDHILL et al. (1976) reported about first experiments of flowcytometrical sperm analysis. Unfortunately, these experiments failed, until the problem of flat cell orientation was first solved for analysis of chicken erythrocytes, employing two sheath-liquid streams (FULWYLER, 1977). The adaptation of the injection tube to wedge shape and inclusion of a second light detector were necessary to gain higher resolution for analysis of flat cells (DEAN et al., 1978; STOVEL et al., 1978), Accordingly, PINKEL et al. (1982) modified their system to oriented spermatozoa in front of the laser beam. These improvements of the flowcytometer were the prerequisites to detect differences in DNA content of X-and $\mathrm{Y}$ - chromosome bearing spermatozoa, first reported by GARNER et al. (1983). In their initial projects, spermatozoa had to be fixed in ethanol for flowcytometrical analysis after being labelled with the fluorochrome 4'-6-diamidino-2-phenylindole (DAPI) in order to achieve two different peaks representing $\mathrm{X}$ - and $\mathrm{Y}$ - sperm populations and to quantify the difference in DNA content between spermatozoa for bull (3.8\%), boar (3.7\%), ram (4.1\%) and rabbit (3.9\%). Due to the labeling process, spermatozoa had no fertilizing 
abilities after sorting, but the experiment approved the differentiation of X- and Ychromosome bearing spermatozoa, opening a new field in biotechnology.

Several further modifications on the flowcytometer and in sample preparation were necessary to obtain higher resolution. JOHNSON and PINKEL (1986) modified a Coulter EPICS V flowcytometer, adding a second fluorescence detector at $0^{\circ}$ and developed a beveled tip for the sample injection tube. Ethanol was still used for the fixation of the spermatozoa, but labeling of spermatozoa was performed now with Hoechst 33342, allowing specific and relatively uniform staining of the DNA (JOHNSON et al., 1987b); JOHNSON et al., 1987a). Despite evidence of its detrimental effect on cell growth (ERBA et al., 1988), Hoechst 33342 was chosen as the least toxic from all DNA fluorescent stains that have potentials to penetrate the plasma membrane of living cells (JOHNSON et al., 1987b). The stain selectively binds to A-T rich regions of DNA and enables the detection of small differences in DNA content. Based on the investigation of offspring produced from flowcytometrically sorted spermatozoa, no mutagenic or teratogenic effects of stain and/or sorting procedure were found so far (PARRILLA et al., 2004; TUBMAN et al., 2004).

The sorting process with a modified standard flowcytometer was relatively slow and allowed separation of about 55 sperm heads/second. In 1988 first evidence was seen that flowcytometrically sorted spermatozoa from domestic animals were able to decondense and form a pronucleus after sperm injection into a hamster oocyte (JOHNSON and CLARKE, 1988). Birth of the first animals inseminated with now viable sorted spermatozoa were reported in the same year (MORRELL et al., 1988). A year later surgical inseminations with sorted spermatozoa into the uterus of does resulted in the birth of offspring with significant shift in sex ratio. Among 37 offspring the proper sex was observed in $94 \%$ and $81 \%$ of animals after insemination with Xand Y-chromosome bearing spermatozoa, respectively (JOHNSON et al., 1989).

Sperm sorting with a flowcytometer requires several technical modifications of a standard apparatus to measure DNA difference in X- and Y-bearing spermatozoa. The flowcytometer has to be equipped with a 5W UV-light, water-cooled argon laser. This may chance now, as the first solid UV-lasers appeared on the market. Besides longer lifetime their signal can be pulsed in order to minimize negative effects on sperm integrity. Until 1996 sperm sorters worked as 'standard-speed' systems, where the samples are sorted with not more than $0.84 \mathrm{~kg} / \mathrm{cm}^{2}$ of pressure giving a sort rate of about 350,000 spermatozoa/h (JOHNSON et al., 1989). New high-speed cell sorters like the MoFlo SX (Dakocytomation, USA) operate at sample pressures up to 4,22 $\mathrm{kg} / \mathrm{cm}^{2}$, allowing to identify 30,000 events/sec and producing up to 15 million sorted spermatozoa of high purity above $90 \%$ per hour. A major reason for this improvement is due to a modified orienting nozzle that improved sperm orientation by more than 70\% (RENS et al., 1998). The nozzle was further refined by XY, Inc. (Fort Collins, Colorado) to incorporate an orientating ceramic nozzle tip (Cytonozzle ${ }^{\mathrm{TM}}$ ) and orientation of the sperm population reaches now $85 \%$.

Preparation and handling of semen before and after sorting has a major impact on semen quality and thereby fertility. Possibly major sources for cell violation are the dye; laser light, electric field and mechanical forces by high liquid pressure (MAXWELL and JOHNSON, 1999). To minimize this damage, constant temperature, osmolarity of buffers, $\mathrm{pH}$ and sterility of staining sheath, collection and cryopreservation media are essential. 
Independent of the type of cell sorter, sample preparation begins with the staining of spermatozoa using Hoechst 33342 stain at $34^{\circ} \mathrm{C}-38^{\circ} \mathrm{C}$ for $60-90$ minutes. Labelled spermatozoa are introduced into the flowcytometer across the sample line under high pressure. Two streams of the sheath fluid with pressure just above the sample pressure surround the core stream in the injection tube. Oriented spermatozoa exit through the vibrating nozzle tip, which produces small droplets, theoretically containing one labelled spermatozoa only. Immediately after their exit, the laser light excites the fluorescent dye and the emitted light is collected through detectors in position $0^{\circ}$ and $90^{\circ}$. The electric signals of the photocells are processed in a computer. Cells failing to fulfill preset criteria are excluded from further analysis. The proper positioned cells are selected as X- or Y-chromosome bearing spermatozoa, according to the amount of emitted light from the flat sperm surface $\left(0^{\circ}\right.$ detector). Based on this signal, the computer sends the signal to the wire loop to electrically charge the droplets accordingly. Charged droplets pass an electro-static field and are separately collected into tubes pre-filled with a collection extender. Sorted spermatozoa are then washed from the sheath fluid by centrifugation and the remaining sperm pellet is extended in a suitable medium. Composition of media differ in among species and also according to the following preservation process (HOLLINSHEAD et al., 2004; LINDSEY et al., 2002; RATH et al., 2003; SEIDEL JR. et al., 1996).

\section{Reanalysis of sorted samples}

Validation of sorted samples are performed immediately after sorting either by reanalysis in the sorter (WELCH and JOHNSON, 1999), by fluorescence in situ hybridization (FISH) (KAWARASAKI et al., 1998) or by PCR (WELCH et al., 1995). Sort reanalysis for DNA has an advantage over FISH and PCR since both techniques may take 3 to $4 \mathrm{~h}$ whereas reanalysis in the flowcytometer requires less than 40 minutes. For reanalysis in the sorter 100,000 spermatozoa are taken preferable from the originally sorted material or can be taken from an extra sort for reanalysis. Cells are sonicated to remove tails and Hoechst 33342 is added at a $10^{\text {th }}$ of the original concentration in order to maintain staining uniformity. Spermatozoa are then analyzed but not sorted at very low speed in order to maximize orientation. DNA difference and histograms are then analyzed by curve fitting to double Gaussian peaks (JOHNSON et al., 1987a) using the programs Summit to Gauss and Gaus7.

\section{Livestock production with sex sorted spermatozoa}

Since the first laboratory tests in the mid eighties, the flowcytometrical sexing technology has undergone major improvements up to a level that is now starting to be of interest for commercial application at least in the bovine. Nevertheless, the output of sex-sorted spermatozoa is still limited compared to the number of a full ejaculate, as each single cell has to be identified and sorted. In consequence, strategies for insemination differ from normal AI and other biotechniques have to be combined with sperm sorting. The Table shows first reported production of offspring with flowcytometrically-sorted spermatozoa as seen in key literature. 
Table

Methods of fertilization with sex sorted spermatozoa in different farm animal species (Methoden der Befruchtung mit nach Geschlecht sortierten Spermatozoen bei verschiedenen Nutztierarten)

\begin{tabular}{|c|c|c|c|c|}
\hline $\begin{array}{c}\text { Kind of } \\
\text { flowcytometer }\end{array}$ & Species & $\begin{array}{c}\text { Semen } \\
\text { preservation }\end{array}$ & $\begin{array}{l}\text { Fertilization } \\
\text { method }\end{array}$ & Reference \\
\hline Standard & Cattle & fresh & Conventional AI & (MORRELL et al., 1988) \\
\hline Standard & Cattle & fresh & IVP(fresh)/ET & (CRAN et al., 1993) \\
\hline Standard & Cattle & fresh & IVP (TG)/ET & (CRAN et al., 1994) \\
\hline Standard & Cattle & Fresh & DIU-AI & (SEIDEL JR. et al., 1997) \\
\hline High speed & Cattle & $\begin{array}{l}\text { fresh and } \\
\text { frozen }\end{array}$ & $\begin{array}{l}\text { Conventional AI } \\
\text { and DIU-AI }\end{array}$ & $\begin{array}{c}\text { (DOYLE et al., 1999; SEIDEL JR. } \\
\text { et al., 1999) }\end{array}$ \\
\hline High speed & Horse & fresh & DIU-AI & (BUCHANAN et al., 2000) \\
\hline High speed & Horse & $\begin{array}{l}\text { fresh and } \\
\text { frozen }\end{array}$ & $\begin{array}{c}\text { DIU-AI } \\
\text { (Hysteroscopy) }\end{array}$ & (LINDSEY et al., 2002) \\
\hline Standard & Human & fresh & IVP/ET & (LEVINSON et al., 1995) \\
\hline Standard & Human & $\begin{array}{l}\text { fresh and } \\
\text { frozen }\end{array}$ & AI, ICSI, IVF & (FUGGER, 1999) \\
\hline Standard & Rabbit & fresh & Surgical AI uterus & (JOHNSON et al., 1989) \\
\hline Standard & Sheep & fresh & ICSI/ET & (CATT et al., 1996) \\
\hline Standard & Sheep & fresh & Laparoscopic AI & (CRAN et al., 1997) \\
\hline High speed & Sheep & & $\begin{array}{c}\text { Laparoscopic AI } \\
\text { and DIU-AI }\end{array}$ & (HOLLINSHEAD et al., 2001) \\
\hline Standard & Swine & fresh & $\begin{array}{c}\text { Surgical AI } \\
\text { oviduct }\end{array}$ & (JOHNSON, 1991) \\
\hline Standard & Swine & fresh & IVF/ET & (RATH et al., 1997) \\
\hline High speed & Swine & frozen & $\begin{array}{l}\text { Surgical AI } \\
\text { oviduct }\end{array}$ & (JOHNSON et al., 2000) \\
\hline High speed & Swine & fresh & ICSI & (PROBST and RATH, 2003) \\
\hline High speed & Swine & fresh & DIU-AI & $\begin{array}{c}\text { (RATH et al., 2004; VAZQUEZ et } \\
\text { al., 2003) }\end{array}$ \\
\hline
\end{tabular}

IVF: In vitro fertilization; IVP: In vitro production including in vitro maturation, in vitro fertilization and in vitro culture; AI: Artificial insemination; DIU-AI: Deep intra-uterine insemination; TG: Deep freezing; ICSI: Intra-cytoplasmatic sperm injection; ET: Embryo Transfer

Cattle:

First experiments to produce offspring from sex-sorted semen had to overcome the problem of low sort rates employing a normal flowcytometer. Therefore, the first calves were produced by a combination of sperm sorting and in vitro production of embryos with subsequent embryo transfer (CRAN et al., 1993; CRAN et al., 1995). Similar experiments were repeated with hormonally synchronized animals recently (PARANACE et al., 2003). High speed flowcytometry helped to obtain more sex sorted spermatozoa in a more reasonable time and first calves were born from insemination with fresh (SEIDEL JR. et al., 1997) and frozen-thawed spermatozoa (SEIDEL et al., 1999; SEIDEL JR. et al., 1999). Meanwhile the technique is offered commercially for bovine spermatozoa. However, field data indicate that fertility is still very variable and depends on bull effects, which are not necessarily completely due to sorting, but may be related to high dilution effects and reduced compensatory mechanisms among spermatozoa. Especially, on farms with moderate fertility, limited quality of sorted semen may be more extinct.

Our own experiments have shown meanwhile that the punctual evaluation of motility is insufficient to judge quality of sex-sorted spermatozoa. Better information can be obtained from a $12 \mathrm{~h}$ thermo-resistant test indicating the loss of motility over time. For example sorted bull spermatozoa loose more than 90 of their motility under such condition employing a regular TRIS extender, whereas unsorted control samples maintain their motility. Similar events can be expected in the female genital tract. 
Recent field experiments however, employing a new set of extenders (Sexcess ${ }^{\circledR}$ ) in a different concept of semen preservation that starts already before and during the sorting process showed meanwhile that the fertilizing competence of sex-sorted spermatozoa can be protected. In total 300 heifers on 190 farms were inseminated with sex-sorted frozen-thawed spermatozoa or unsorted controls. Pregnancy rates as determined by ultrasonography showed no differences anymore between controls and sex-sorted spermatozoa. Similar data were also obtained with fresh sex-sorted spermatozoa that were used for normal AI in 70 heifers over a three-day period after sorting. Also in beef breeds, pregnancy rates as determined by ultrasonography between days 30 and 60 were equal between groups when Sexcess ${ }^{\circledR}$ was used.

Swine:

Production of piglets with sex-sorted spermatozoa requires more sophisticated techniques than in other species. Reasons are the demand of very high sperm number per insemination, more than one insemination per estrous cycle, high amount of sperm losses during the transportation through the female genital tract, high variability in the time of ovulation relative to onset of estrus, parallel ovulations in both horns and the anatomic shape of the uterus. In consequence, for routine AI more than 1 billion spermatozoa are inseminated at least twice per estrous cycle. As it will be impossible to satisfy such high demand of porcine spermatozoa with the current sperm sexing technology, new systems for AI have to be developed. In a recent basic study (KRUEGER et al., 1999) we could show that surgical insemination of unsorted spermatozoa directly into the tip of the uterine horn allows lowering the sperm number to 5 million spermatozoa without significant loss of fertility. Similar data were shown by Johnson (JOHNSON, 1991) when he inseminated sex-sorted spermatozoa directly into the oviduct. These techniques are of course not suitable under commercial conditions, but they led to the development of a device that can be introduced nonsurgically through the cervix into the tip of the uterine horn. With such flexible Firflex $^{\circledR}$ catheter the inventors were able to produce offspring with semen that had passed a sperm sorter but was not sorted (VAZQUEZ et al., 2003). They inseminated 100,000 million spermatozoa and obtained acceptable litter sizes. In the same year, we could show similar results using 50 million life sex sorted spermatozoa (RATH et al., 2003). Latest data from Sydney University indicate that with the same device sexsorted/frozen-thawed spermatozoa are capable to produce offspring of the desired sex (BATHGATE et al., unpublished). In all mentioned cases sows were inseminated only once per estrous cycle. Unfortunately, the insemination device can only be used in sows as the genital tract of gilts is to narrow.

Therefore alternative methods had to be developed in order to minimize the amount of spermatozoa. First embryos were already produced with sexed spermatozoa in 1993 (RATH et al., 1993). A year later we could show that gamete intrafallopian transfer might be an alternative for IVF, especially, when laboratory equipment does not allow fertilization in vitro (RATH et al., 1994). Offspring were born after IVF of in vivo matured oocytes (RATH et al., 1997) and of in vitro matured oocytes (ABEYDEERA et al., 1998; RATH et al., 1999).

Finally, a method for the most effective use of sexed spermatozoa was established with the introduction of intra-cytoplasmatic sperm injection (ISCI) (PROBST and RATH, 2003). For fertilization only a single sperm cell is introduced into the cytoplasm of a 
mature oocyte. Several litters with acceptable litter sizes were born. However, ICSI and IVF need to be improved further before the technique can be used on a larger scale. Especially the embryo transfer of early embryonic stages requires attention and has to be further developed into a non-surgical system. It is foreseeable that the demand for sex-sorted boar spermatozoa will raise in the coming years as the first European States like Norway have already decided to forbid castration of male piglets for the year 2009 onwards.

\section{Sheep:}

The sperm sorting technology is highly requested for sheep in countries like Australia and New Zealand, where this species play in major role in husbandry. Accordingly, most of the sheep work has been done at Sydney University. The first lamb from sexsorted spermatozoa was produced by ICSI with a fresh spermatozoon (CATT et al., 1996). Lambs were then produced after sex-sorting and laparoscopic insemination using either $10 \times 10^{6}$ non-frozen (CRAN et al., 1997) or 2-4 $\times 10^{6}$ frozen-thawed spermatozoa (HOLLINSHEAD et al., 2002). Lately, offspring have been produced by IVF of oocytes aspirated from hormone-stimulated prepuberal lambs (MORTON et al., 2004).

\section{Horses:}

Several trials have shown the production of foals with sex-sorted spermatozoa as recently summarized in a review article by (LINDSEY et al., 2001). SCHMID et al. (2000) reported about the first foal after surgical insemination with 150,000 spermatozoa. The first successful non-surgical insemination was performed in a study by BUCHANAN et al. (2000). Mares were inseminated once with 25 million motile spermatozoa, diluted in $1 \mathrm{ml}$ of a skim milk extender. The semen was deposited into the tip of the uterine horn ipsi-lateral to the pre-ovulatory follicle. At 16 days after AI, pregnancy rates were $30 \%$ but decreased to $10 \%$ until day 60 . A second group of mares was inseminated in the same way, except that $4 \%$ of egg yolk was added to the skim milk extender. Pregnancy rates were $50 \%$ on day 16 after AI and only another $10 \%$ were lost until day 60 . Sex ratios of offspring were 87 to $89 \%$ of the desired sex. As in other species, the site of semen deposition should be closer to the utero-tubal junction in order to minimize sperm losses during sperm transport in the female genital tract. A valuable method is the video-endoscopically guided hysteroscopic insemination (MORRIS et al., 2000). In a recent study (LINDSEY et al., 2002) showed that a pregnancy rate of $25 \%$ could be obtained with sorted semen employing this technology.

In an earlier trial LINDSEY et al. (2000) investigated if semen can be stored for $18 \mathrm{~h}$ prior to sexing. Although the number of replicates was low, pregnancy rates after AI with pre-stored semen were slightly better (35\%) as compared to samples sorted directly after semen collection (30\%).

In addition to fresh sexed, fresh stored sexed and unsorted semen, LINDSEY et al. (2000 and 2002) used sexed frozen/thawed semen at low concentrations for AI in two subsequent trials. Better pregnancy rates were obtained with 20 million pre-stored sexed spermatozoa being inseminated hysteroscopically. Insemination results employing 5 million spermatozoa did not differ between fresh sorted and unsorted 
frozen semen, whereas sexed frozen/thawed samples resulted only low in pregnancy rates $(13 \%)$.

Freezing of sorted semen needs further improvement before recommended for commercial AI. In a running field experiment, we test semen from two stallions that was frozen after sorting in a modified lactose-egg yolk extender. Mares are currently inseminated in Australia.

In summary, flowcytometry based sperm sorting is the only available method that has been shown to produce high purity of sex chromosome selection. Several major improvements have been made in the past years, especially by invention of high speed cell sorting and improved orientation of cells in front of the Laser. Nevertheless, the limitations of the technology due to the principle of single sperm cell analysis have to be recognized and even with further technical improvements it is unlikely that the output will reach the amount of a normal insemination dosage, especially in the porcine. In combination with other biotechnologies, bovine sexed spermatozoa are already commercially available. In other species intensive research is required to provide sufficient sexed spermatozoa.

Finally, it has to be mentioned that the procedure underlies several patents and license regulations of XY-Inc in Colorado, USA and other institutions.

\section{References}

ABEYDEERA, L.R.; JOHNSON, L.A.; WELCH, G.R.; WANG, W.H.; BOQUEST, A.C.; CANTLEY, T.C.; RIEKE, A.; DAY, B.N.:

Birth of piglets preselected for gender following in vitro fertilization of in vitro matured pig oocytes by $\mathrm{X}$ and $\mathrm{Y}$ chromosome bearing spermatozoa sorted by high speed flow cytometry. Theriogenology $\mathbf{5 0}$ (1998), 981-988

ALI, J.I.; ELDRIDGE, F.E.; KOO, G.C.; SCHANBACHER, B.D.:

Enrichment of bovine $\mathrm{X}$ - and Y-chromosome-bearing sperm with monoclonal $\mathrm{H}$-Y antibodyfluorescence-activated cell sorter. Arch. Androl. 24 (1990), 235-245

BEAL, W.E., WHITE, L.M.; GARNER, D.L.:

Sex ratio after insemination of bovine spermatozoa isolated using a bovine serum albumin gradient. $\mathrm{J}$. Anim. Sci. 58 (1984), 1432-1436

BEERNINK, F.J.; ERICSSON, R.J.:

Male sex preselection through sperm isolation. Fertil. Steril. 38 (1982), 493-495

BENNETT, D.; BOYSE, E.A.:

Sex ratio in progeny of mice inseminated with sperm treated with H-Y antiserum. Nature 246 (1973), 308-309

BHATTACHARYA, B.C.:

Sex control in mammals. Z. Tierzücht. Züchtungsbiol. 72 (1958), 250-254

BHATTACHARYA, B.C.:

Different sedimentation rates of $\mathrm{X}$ - and $\mathrm{Y}$ - sperm and the question of arbitrary sex determination. Z. Wiss. Zool. 166 (1962), 203-250

BHATTACHARYA, B.C.; BANGHAM, A.D.; CRO, R.J.; KEYNES, R.D.; ROWSON, L.E.: An attempt to predetermine the sex of calves by artificial insemination with spermatozoa separated by sedimentation. Nature 211 (1966), 863

BLECHER, S.R.; HOWIE, R.; LI, S.; DETMAR, J.; BLAHUT, L.M.:

A new approach to immunological sexing of sperm. Theriogenology 52 (1999), 1309-1321

BLOTTNER, S.; BOSTEDT, H.; MEWES, K.; PITRA, C.:

Enrichment of bovine $\mathrm{X}$ and $\mathrm{Y}$ spermatozoa by free-flow electrophoresis. Zentralbl. Veterinärmed. A 41 (1994), 466-474

BUCHANAN, B.R.; SEIDEL JR., G.E.; MCCUE, P.M.; SCHENK, J.L.; HERICKHOFF, L.A.; SQUIRES, E.L.: Insemination of mares with low numbers of either unsexed or sexed spermatozoa. Theriogenology 53 (2000), 1333-1344

CATT, S.L.; CATT, J.W.; GOMEZ, M.C.; MAXWELL, W.M.; EVANS, G.: 
Birth of a male lamb derived from an in vitro matured oocyte fertilised by intracytoplasmic injection of a single presumptive male sperm. Vet. Rec. 139 (1996), 494-495

CORIAT, A.M.; VALLELEY, E.; FERGUSON, M.W.; SHARPE, P.T.:

Chromosomal and temperature-dependent sex determination: the search for a conserved mechanism. J. Exp. Zool. 270 (1994), 112-116

CRAN, D.G.; COCHRANE, D.J.; JOHNSON, D.J.; WEI, H.; LU, K.H.; POLGE, C.:

Separation of $\mathrm{X}$ - and Y-chromosome bearing bovine sperm by flow cytometry for use in IVF. Theriogenology 41 (1994), 183-183 (Abstract)

CRAN, D.G.; JOHNSON, L.A.; MILLER, N.G.; COCHRANE, D.; POLGE , C.:

Production of bovine calves following separation of $\mathrm{X}$ - and Y-chromosome bearing sperm and in vitro fertilisation. Vet. Rec. 132 (1993), 40-41

CRAN, D.G.; JOHNSON, L.A.; POLGE, C.:

Sex preselection in cattle: a field trial. Vet. Rec. 136 (1995), 495-496

CRAN, D.G.; MCKELVEY, W.A.C.; KING, M.E.; DOLMAN, D.F.; MCEVOY, T.G.; BROADBENT, P.J.; ROBINSON, J.J.:

Production of lambs by low dose intrauterine insemination with flow cytometrically sorted and unsorted

DAVIS, R.M.: sperm. Theriogenology 47 (1997), 267

Localisation of male determining factors in man: a thorough review of structural anomalies of the $\mathrm{Y}$ chromosome. J. Med. Genet. 18 (1981), 161-195

DEAN, P.N.; PINKEL, D.; MENDELSOHN, M.L.:

Hydrodynamic orientation of sperm heads for flow cytometry. Biophys. J. 23 (1978), 7-13

DMOWSKI, W.P., GAYNOR, L.; RAO, R.; LAWRENCE, M.; SCOMMEGNA, A.:

Use of albumin gradients for $\mathrm{X}$ and $\mathrm{Y}$ sperm separation and clinical experience with male sex preselection. Fertil. Steril. 31 (1979), 52-57

DORIZZI, M.; RICHARD-MERCIER, N.; PIEAU, C.:

The ovary retains male potential after the thermosensitive period for sex determination in the turtle Emys orbicularis. Differentiation 60 (1996), 193-201

DOYLE, S.P.; SEIDEL, G.E.; SCHENK, J.L.; HERICKHOFF, L.A.; CRAN, D.G.; GREEN, R.D.:

Artificial insemination of lactating Angus cows with sexed semen. Proc. Western Section Am. Soc. Anim. Sci. 50 (1999), 203-205

ENGELMANN, U.; KRASSNIGG, F.; SCHATZ, H.; SCHILL, W.B.:

Separation of human X and Y spermatozoa by free-flow electrophoresis. Gamete Res. 19 (1988), 151160

ERBA, E.; UBEZIO, P.; BROGGINI, M.; PONTI, M.; D'INCALCI, M.:

DNA damage, cytotoxic effect and cell-cycle perturbation of Hoechst 33342 on L1210 cells in vitro. Cytometry 9 (1988), 1-6

ERICKSON, R.P.; LEWIS, S.E.; BUTLEY, M.:

Is Haploid gene expression possible for sperm antigens? J Reprod. Immunol. 3 (1981), 195-217

ERICSSON, R.J.; LANGEVIN, C.N.; NISHINO, M.:

Isolation of fractions rich in human Y sperm. Nature 246 (1973), 421-424

FLAHERTY, S.P.; MICHALOWSKA, J.; SWANN, N.J.; DMOWSKI, W.P.; MATTHEWS, C.D.; AITKEN, R.J.:

Albumin gradients do not enrich Y-bearing human spermatozoa. Hum. Reprod. 12 (1997), 938-942

FUGGER, E.F.:

Clinical experience with flow cytometric separation of human X- and Y-chromosome bearing sperm. Theriogenology 52 (1999), 1435-1440

FULWYLER, M.J.:

Hydrodynamic orientation of cells. J. Histochem. Cytochem. 25 (1977), 781-783

GABRIEL, W.N.; BLUMBERG, B.; SUTTON, S.; PLACE, A.R.; LANCE, V.A.:

Alligator aromatase cDNA sequence and its expression in embryos at male and female incubation temperatures. J. Exp. Zool. 290 (2001), 439-448

GARNER, D.L.; GLEDHILL, B.L.; PINKEL, D.; LAKE, S.; STEPHENSON, D.; VAN DILLA, M.A.; JOHNSON, L.A.:

Quantification of the X- and Y-chromosome-bearing spermatozoa of domestic animals by flow cytometry. Biol. Reprod. 28 (1983), 312-321

GLEDHILL, B.L.; LAKE, S.; STEINMETZ, L.L.; GRAY, J.W.; CRAWFORD, P.N. D.; VAN DILLA, M.A.: Flow microfluorometric analysis of sperm DNA content: effect of cell shape on the fluorescence distribution. J. Cell Physiol. 87 (1976), 367-375

HANCOCK, R.J.:

Comparison of effects of normal rabbit sera and anti-cock sperm sera on rabbit sperm, including comparison of effects on the sex ratio. Biol. Reprod. 18 (1978), 510-515 
HARLEY, V.; JACKSON, D.I.; HEXTALL, P.J.; HAWKINS, J.R.; BERKOVITZ, G.D.; SOCKANATHAN, S.; LOVELL-BADGE, R.; GOODFELLOW, P.N.:

DNA binding activity of recombinant SRY from normal males and XY females. Science 255 (1992), 453-456

HENDRIKSEN, P.J.; TIEMAN, M.; VAN DER, L.T.; JOHNSON, L.A.:

Binding of anti-H-Y monoclonal antibodies to separated $\mathrm{X}$ and $\mathrm{Y}$ chromosome-bearing porcine and bovine sperm. Mol. Reprod. Dev. 35 (1993), 189-196

HOLLINSHEAD, F.K.; EVANS, G.; EVANS, K.M.; CATT, S.L.; MAXWELL, W.M.; O'BRIEN, J.K.:

Birth of lambs of a pre-determined sex after in vitro production of embryos using frozen-thawed sexsorted and re-frozen-thawed ram spermatozoa. Reproduction 127 (2004), 557-568

HOLLINSHEAD, F.K.; O'BRIEN, J.K.; HE, L.; MAXWELL, W.M.C.; EVANS, G.:

Pregnancies after insemination of ewes with sorted, cryopreserved ram spermatozoa. Proc. Soc. Reprod. Biol. 32 (2001), 20 (Abstract)

HOLLINSHEAD, F.K.; O'BRIEN, J.K.; MAXWELL, W.M.; EVANS, G.:

Production of lambs of predetermined sex after the insemination of ewes with low numbers of frozenthawed sorted X- or Y-chromosome-bearing spermatozoa. Reprod. Fertil. Dev. 14 (2002), 503-508

HUNTER, R.H.F.:

Sex determination, differentiation and intersexuality in placental mammals. Cambridge University Press (1995)

JACOBS, P.A.; STRONG, J.A.:

A case of human intersexuality having a possible XXY sex-determining mechanism. Nature 183 (1959), 302-303

JAGER, R.J.; ANVRET, M.; HALL, K.; SCHERER, G.:

A human XY female with a frame shift mutation in the candidate testis-determining gene SRY. Nature 348 (1990), 452-454

JOHNSON, L.A.:

Sex preselection in swine: Altered sex ratios in offspring following surgical insemination of flow sorted X- and Y-bearing sperm. Reprod. Dom. Anim. 26 (1991), 309-314

JOHNSON, L.A.; CLARKE, R.N.:

Flow sorting of $\mathrm{X}$ and $\mathrm{Y}$ chromosome-bearing mammalian sperm: activation and pronuclear development of sorted bull, boar, and ram sperm microinjected into hamster oocytes. Gamete Res. 21 (1988), 335-343

JOHNSON, L.A.; FLOOK, J.P.; HAWK, H.W.:

Sex preselection in rabbits: live births from X and Y sperm separated by DNA and cell sorting. Biol. Reprod. 41 (1989), 199-203

JOHNSON, L.A., FLOOK, J.P.; LOOK, M.V.:

Flow cytometry of $\mathrm{X}$ and $\mathrm{Y}$ chromosome-bearing sperm for DNA using an improved preparation method and staining with Hoechst 33342. Gamete Res. 17 (1987b), 203-212

JOHNSON, L.A.; FLOOK, J.P.; LOOK, M.V.; PINKEL, D.:

Flow sorting of $\mathrm{X}$ and $\mathrm{Y}$ chromosome-bearing spermatozoa into two populations. Gamete Res. 16 (1987a), 1-9

JOHNSON, L.A.; GUTHRIE, H.D.; FISHER, P.; MAXWELL, W.M.C.; WELCH, G.R.; GERRETT, W.M.:

Cryopreservation of flow cytometrically sorted boar sperm: effects on in vivo embryo development. J. Anim. Sci. 78 (suppl. 1) (2000) 198-198 (Abstract)

JOHNSON, L.A.; PINKEL, D.:

Modification of a laser-based flow cytometer for high-resolution DNA analysis of mammalian spermatozoa. Cytometry 7 (1986), 268-273

KANEKO, S.; YAMAGUCHI, J.; KOBAYASHI, T.; IIZUKA, R.:

Separation of human $\mathrm{X}$ - and Y-bearing sperm using percoll density gradient centrifugation. Fertil. Steril. 40 (1983), 661-665

KAWARASAKI, T.; WELCH, G.R.; LONG, C.R.; YOSHIDA, M.; JOHNSON, L.A.:

Verification of flow cytometorically-sorted X- and Y-bearing porcine spermatozoa and reanalysis of spermatozoa for DNA content using the fluorescence in situ hybridization (FISH) technique. Theriogenology 50 (1998), 625-635

KOBAYASHI, J.; OGURO, H.; UCHIDA, H.; KOHSAKA, T.; SASADA, H.; SATO, E.: Assessment of bovine $\mathrm{X}$ - and Y-bearing spermatozoa in fractions by discontinuous percoll gradients with rapid fluorescence in situ hybridization. J. Reprod. Dev. 50 (2004), 463-469

KOOPMAN, P.; GUBBAY, J.; VIVIAN, N.; GOODFELLOW, P.; LOVELL-BADGE, R.: Male development of chromosomally female mice transgenic for Sry. Nature 351 (1991), 117-121

KOOPMAN, P.; MUNSTERBERG, A.; CAPEL, B.; VIVIAN, N.; LOVELL-BADGE, R.: Expression of a candidate sex-determining gene during mouse testis differentiation. Nature 348 (1990), 450-452 
KRUEGER, C.; RATH, D.; JOHNSON, L.A.:

Low dose insemination in synchronized gilts. Theriogenology 52 (1999), 1363-1373

LEVINSON, G.; KEYVANFAR, K.; WU, J.C.; FUGGER, E.F.; FIELDS, R.A.; HARTON, G.L.; PALMER, F.T.; SISSON, M.E.; STARR, K.M.; DENNISON-LAGOS, L.:

DNA-based X-enriched sperm separation as an adjunct to preimplantation genetic testing for the prevention of X-linked disease. Hum. Reprod. 10 (1995), 979-982

LINDSEY, A.C.; BRUEMMER, J.E.; SQUIRES, E.L.:

Low dose insemination of mares using non-sorted and sex-sorted sperm. Anim. Reprod. Sci. 68 (2001), 279-289

LINDSEY, A.C.; MORRIS, L.H.; ALLEN, W.R.; SCHENK, J.L.; SQUIRES, E.L.; BRUEMMER, J.E.: Hysteroscopic insemination of mares with low numbers of nonsorted or flow sorted spermatozoa. Equine Vet. J. 34 (2002), 128-132

LINDSEY, A.C.; MUCKLE, L.K.; SQUIRES, E.L.:

Effect of caffeine stimulation on stallion sperm motion characteristics following 18-h-storage, flowsorting and cryopreservation. Theriogenology 59 (2000), 510 (Abstract)

LOPEZ, O.; MATA, A.; ANTICH, M.; BASSAS, L.:

Sperm selection by PD-10 sephadex columns: comparison with SpermPrep filtration and Percoll centrifugation. Hum. Reprod. 8 (1993), 732-736

MANGER, M.; BOSTEDT, H.; SCHILL, W.B.; MILEHAM, A.J.:

Effect of sperm motility on separation of bovine X- and Y-bearing spermatozoa by means of free-flow electrophoresis. Andrologia 29 (1997), 9-15

MAXWELL, W.M.; JOHNSON, L.A.:

Physiology of spermatozoa at high dilution rates: the influence of seminal plasma. Theriogenology 52 (1999), 1353-1362

MCLAREN, A.; MONK, M.:

X-chromosome activity in the germ cells of sex-reversed mouse embryos. J. Reprod. Fertil. 63 (1981), 533-537

MORRELL, J.M.; KEELER, K.D.; NOAKES, D.E.; MACKENZIE, N.M.; DRESSER, D.W.: Sexing of sperm by flow cytometry. Vet. Rec. 122 (1988), 322-324

MORRIS, L.H.; HUNTER, R.H.; ALLEN, W.R.:

Hysteroscopic insemination of small numbers of spermatozoa at the uterotubal junction of preovulatory mares. J. Reprod. Fertil. 118 (2000), 95-100

MORTON, K.M.; CATT, S.L.; HOLLINSHEAD, F.K.; MAXWELL, W.M.C.; EVANS, G.:

Lambs born after in vitro embryo production from prepubertal lamb oocytes and frozen-thawed unsorted and sex-sorted spermatozoa. Reprod. Fertil. Dev. 16 (2004), 260-260

MORUZZI, J.F.:

Selecting a mammalian species for the separation of X- and Y-chromosome-bearing spermatozoa. J. Reprod. Fertil. 57 (1979), 319-323

MULLER, U.; DONLON, T.; SCHMID, M.; FITCH, N.; RICHER, C.L.; LALANDE, M.; LATT, S.A.:

Deletion mapping of the testis determining locus with DNA probes in 46,XX males and in 46,XY and 46,X,dic(Y) females. Nucleic Acids Res. 14 (1986), 6489-6505

PAGE, D.; MOSHER, R.; SIMPSON, E.M.; FISHER, E.M.; MARDON, G.; POLLACK, J.; MCGILLIVRAY,

B.; DE LA, C.A.; BROWN, L.G.:

The sex-determining region of the human Y chromosome encodes a finger protein. Cell 51 (1987), 1091-1104

PALMER, M.S.; SINCLAIR, A.H.; BERTA, P.; ELLIS, N.A.; GOODFELLOW, P.N.; ABBAS, N.E.; FELLOUS, M:

Genetic evidence that ZFY is not the testis-determining factor. Nature 342 (1989), 937-939

PARANACE, M.; MEDINA, M.; CATTANEO, L.; CABALLERO, J.; CERRATE, H.; DALLA LASTA, M.; KAISER:

Embryo production using sexed semen in superovulated cows and heifers. Theriogenology 59 (2003), 513 (Abstract)

PARRILLA, I.; VAZQUEZ, J.M.; CUELLO, C.; GIL, M.A.; ROCA, J.; DI BERARDINO, D.; MARTINEZ, E.A.:

Hoechst 33342 stain and u.v. laser exposure do not induce genotoxic effects in flow-sorted boar spermatozoa. Reproduction. 128 (2004), 615-621

PIEAU, C.; DORIZZI, M.; RICHARD-MERCIER, N.:

Temperature-dependent sex determination and gonadal differentiation in reptiles. EXS (2001), 117-141

PINKEL, D.; GARNER, D.L.; GLEDHILL, B.L.; LAKE, S.; STEPHENSON, D.; JOHNSON, L.A.:

Flow cytometric determination of the proportions of X-and Y-chromosome-bearing sperm in samples of purportedly separated bull sperm. J. Anim. Sci. 60 (1985), 1303-1307

PINKEL, D.; LAKE, S.; GLEDHILL, B.L.; VAN DILLA, M.A.; STEPHENSON, D.; WATCHMAKER, G.: 
High resolution DNA content measurements of mammalian sperm. Cytometry 3 (1982), 1-9

PROBST, S.; RATH, D.:

Production of piglets using intracytoplasmic sperm injection (ICSI) with flowcytometrically sorted boar semen and artificially activated oocytes. Theriogenology 59 (2003), 961-973

PYRZAK, R.:

Separation of X- and Y-bearing human spermatozoa using albumin gradients. Hum. Reprod. 9 (1994), 1788-1790

QUINLIVAN, W.L.; PRECIADO, K.; LONG, T.L.; SULLIVAN, H.:

Separation of human X and Y spermatozoa by albumin gradients and Sephadex chromatography. Fertil. Steril. 37 (1982), 104-107

RATH, D.; JOHNSON, L.A.; DOBRINSKY, J.R.; WELCH, G.R.; NIEMANN, H.:

Production of piglets preselected for sex following in vitro fertilization with $\mathrm{X}$ and $\mathrm{Y}$ chromosomebearing spermatozoa sorted by flow cytometry. Theriogenology 47 (1997), 795-800

RATH, D.; JOHNSON, L.A.; WELCH, G.; NIEMANN, H.: Successful gamete intrafallopian transfer (GIFT) in the porcine. Theriogenology 41 (1994), 1173-1179

RATH, D.; JOHNSON, L.A.; WELCH, G.R.:

In vitro culture of porcine embryos: Development to blastocysts after in vitro fertilization (IVF) with flow cytometrically sorted and unsorted semen. Theriogenology 39 (1993) 293 (Abstract)

RATH, D.; LONG, C.R.; DOBRINSKY, J.R.; WELCH, G.R.; SCHREIER, L.L.; JOHNSON, L.A.: In vitro production of sexed embryos for gender preselection: high-speed sorting of X-chromosomebearing sperm to produce pigs after embryo transfer. J. Anim. Sci.77 (1999), 3346-3352

RATH, D.; RUIZ, S.; SIEG, B.:

Birth of female piglets following intrauterine insemination of a sow using flow cytometrically sexed boar semen. Vet. Rec. 152 (2003), 400-401

RENS, W.; WELCH, G.R.; JOHNSON, L.A.:

A novel nozzle for more efficient sperm orientation to improve sorting efficiency of $\mathrm{X}$ and $\mathrm{Y}$ chromosome-bearing sperm. Cytometry 33 (1998), 476-481

ROHDE, W.; PORSTMANN, T.; PREHN, S.; DORNER, G.:

Gravitational pattern of the Y-bearing human spermatozoa in density gradient centrifugation. J. Reprod. Fertil. 42 (1975), 587-591

ROSS, A.; ROBINSON, J.A.;EVANS, H.J.:

Failure to confirm separation of $\mathrm{X}$ - and Y-bearing human sperm using BSA gradients. Nature 253 (1975), 354-355

SCHILLING, E.; THORMAEHLEN, D.:

Enrichment of human X- and Y-chromosome bearing spermatozoa by density gradient centrifugation. Andrologia 9 (1977), 106-110

SCHMID, R.L.; KATO, H.; HERICKHOFF, L.A.; SCHENK, J.L.; MCCUE, P.M.; CHUNG, Y.G.: SQUIRES, E.L.:

Effects of follicular fluid or progesterone on in vitro maturation of equine oocytes before intracytoplasmatic sperm injection with nonsorted and sex sorted spermatozoa. J. Reprod. Fertil. Suppl. 56 (2000), 519-525

SEIDEL, G.E.; CRAN, D.G.; HERICKHOFF, L.A.; SCHENK, J.L.; DOYLE, S.P.; GREEN, R.D.: Insemination of heifers with sexed frozen or sexed liquid semen. Theriogenology 51 (1999), 400 (Abstract)

SEIDEL JR., G.E.:

Sexing mammalian sperm-intertwining of commerce, technology, and biology. Anim. Reprod. Sci 79 (2003), 145-156

SEIDEL JR., G.E.; ALLEN, C.H.; JOHNSON, L.A.; HOLLAND, M.D.; BRINK, Z.; WELCH, G.R.; GRAHAM, J.K.; CATTELL, M.B.:

Uterine horn insemination of heifers with very low numbers of nonfrozen and sexed spermatozoa. Theriogenology 48 (1997), 1255-1264

SEIDEL JR., G.E.; JOHNSON, L.A.; ALLEN, C.A.; WELCH, G.R.; HOLLAND, M.D.; BRINK, Z.; CATTELL, M.B.:

Artificial insemination with X- and Y-bearing bovine sperm. Theriogenology 45 (1996), 309 (Abstract)

SEIDEL JR., G.E.; SCHENK, J.L.; HERICKHOFF, L.A.; DOYLE, S.P.; BRINK, Z.; GREEN, R.D.; CRAN, D.G.:

SEVINC, A.:

Insemination of heifers with sexed sperm. Theriogenology 52 (1999), 1407-1420

Experiments on sex control by electrophoretic separation of spermatozoa in the rabbit. J. Reprod. Fertil. 16 (1968), 7-14

SHASTRY, P.R.; HEGLE, U.C.; RAO, S.S.: 
Use of Ficoll-sodium metrizoate density gradient to separate human X-and Y-bearing spermatozoa. Nature 269 (1977), 58-60

SHIRAI, M.; MATSUDA, S.; MITSUKAWA, S.:

Electrophoretic separation of X- and Y-chromosome-bearing sperm in human semen. Tohoku J. Exp. Med. 113 (1974), 273-281

SHISHITO, S.; SHIRAI, M.; MATSUDA, S.:

Galvanic separation of X- and Y-bearing human spermatozoa. Andrologia 6 (1974), 17-24

SILLS, E.S.; KIRMAN, I.; COLOMBERO, L.T.; HARIPRASHAD, J.; ROSENWAKS, Z.; PALERMO, G.D.: $\mathrm{H}-\mathrm{Y}$ antigen expression patterns in human X- and Y-chromosome-bearing spermatozoa. Am. J. Reprod. mmunol. 40 (1998), 43-47

SPRENGER, E.; BOHM, N.; SANDRITTER, W.:

Flow fluorescence cytophotometry for ultra-rapid DNA measurements on large cell populations. Histochemie 26 (1971), 238-257

STOVEL, R.T.; SWEET, R.G.; HERZENBERG, L.A.:

A means for orienting flat cells in flow systems. Biophys. J. 23 (1978), 1-5

TUBMAN, L.M.; BRINK, Z.; SUH, T.K.; SEIDEL JR., G.E.:

Characteristics of calves produced with sperm sexed by flow cytometry/cell sorting. J. Anim. Sci. 82 (2004), 1029-1036

UWLAND, J.; WILLEMS, C.M.:

Results of semen separation using a modified electromagnetochemical method. Tijdschr. Diergeneeskd. 100 (1975), 911-914

VAZQUEZ, J.M.; MARTINEZ, E.A.; PARRILLA, I.; ROCA, J.; GIL, M.A.; VAZQUEZ, J.L.:

Birth of piglets after deep intrauterine insemination with flow cytometrically sorted boar spermatozoa. Theriogenology 59 (2003), 1605-1614

VIDAL, F.; MORAGAS, M.; CATALA, V.; TORELLO, M.J.; SANTALO, J.; CALDERON, G.; GIMENEZ, C.; BARRI, P.N.; EGOZCUE, J.; VEIGA, A.:

Sephadex filtration and human serum albumin gradients do not select spermatozoa by sex chromosome: a fluorescent in-situ hybridization study. Hum. Reprod. 8 (1993), 1740-1743

WANG, H.X.; FLAHERTY, S.P.; SWANN, N.J.; MATTHEWS, C.D.:

Assessment of the separation of $\mathrm{X}$ - and Y-bearing sperm on albumin gradients using double-label fluorescence in situ hybridization. Fertil. Steril. 61 (1994a), 720-726

WANG, H.X.; FLAHERTY, S.P.; SWANN, N.J.; MATTHEWS, C.D.:

Discontinuous Percoll gradients enrich X-bearing human spermatozoa: a study using double-label fluorescence in-situ hybridization. Hum. Reprod. 9 (1994b), 1265-1270

WELCH, G.R.; JOHNSON, L.A.:

Sex preselection: laboratory validation of the sperm sex ratio of flow sort. Theriogenology 52 (1999), 1343-1352

WELCH, G.R.; WALDBIESER, G.C.; WALL, R.J.; JOHNSON, L.A.:

Flow cytometric sperm sorting and PCR to confirm separation of X- and Y-chromosome bearing bovine sperm. Animal Biotechnology 6 (1995), 131-139

ZAVOS, P.M.:

Sperm separation attempts via the use of albumin gradients in rabbits. Theriogenology 23 (1985), 875879

Received: 2005-04-18

Accepted: 2005-11-28

Corresponding author

Prof. DETHLEF RATH

Institute of Animal Breeding Mariensee, (FAL)

Hoeltystr. 10

31535 NEUSTADT

GERMANY

E-mail: rath@tzv.fal.de 